\title{
STRUKTUR DAN AGENSI: ANALISA SOSIAL TERHADAP PERILAKU KORUPSI
}

\author{
Oleh: \\ Cokorde Istri Kumara Dewi \\ Inspektorat Pemerintah Provinsi Bali \\ Cok.inspektorat@gmail.com
}

\begin{abstract}
Corruption is now increasingly widespread in Indonesia. Those who are caught in the act of corruption ranging from high-ranking state officials to village heads. Eradication of corruption is getting harder but corruption is still happening. This paper tries to read corruption from the sociological point of view based on the assumption that corruption is a violation of social norms in a society. If the violations of norms trigger corruption, the strengthening of norms through the path of religion becomes an offer that needs to be considered. The data collection by means of document study was analyzed by interpretive descriptive techniques.
\end{abstract}

Keywords: corrupption, sociology, religion

\begin{abstract}
Abstrak
Korupsi kini makin marak di Indonesia, yang tertangkap tangan melakukan korupsi mulai dari pejabat tinggi negara sampai kepala desa. Pemberantasan korupsi semakin keras namun korupsi masih saja terjadi. Tulisan ini mencoba membaca korupsi dari sudut pandang sosiologi berangkat dari asumsi bahwa korupsi adalah pelanggaran terhadap norma sosial yang berkembang dalam masyarakat. Ketika pelanggaran norma sebagai pemicu korupsi, maka penguatan norma melalui jalan agama menjadi tawaran yang perlu dipertimbangkan. Pengumpulan data dengan cara studi dokumen, dianalisis dengan teknik deskripsif interpretatif.
\end{abstract}

Kata kunci: korupsi, sosiologi, agama

\section{PENDAHULUAN}

Berita yang cukup mengejutkan disampaikan oleh Mendagri pada tanggal 10 September 2018 bahwa 2.150 ASN terlibat kasus korupsi dan mereka segera akan dipecat dari jabatannya. Kondisi yang sungguh memprihatinkan di tengah gencarnya Komisi Pemberantasan Korupsi melakukan upaya-upaya untuk mencegah dan memberantas korupsi di Indonesia. Media local di Bali juga memberitakan bahwa beberapa kepala desa kini sedang berurusan dengan hukum karena tindakan korup yang mereka lakukan dalam mengelola dana desa yang digelontorkan pemerintah. Orng-orang sepertinya tidak merasa kapok untuk melakukan korupsi di Indonesia. Cukup ironis yang ditampilkan di media social bahwa para koruptor tersenyum-senyum manakala diwawancarai awak media tentang kasus yang menjerat mereka. Hal ini tampak manakala anggota DPRD Kota Malang yang ditangkap KPK secara berjamaah melakukan korupsi. Mereka tampak senyum dan sedikitpun tidak 
menampakkan rasa bersalah ketika digiring KPK dengan memakai rompi orange.

Kondisi seperti ini sungguh memalukan dan harus diberantas demi masa depan bangsa yang lebih bagus. Berdasarkan latar tersebut di atas maka tulisan ini bermaksud untuk mengungkap mengapa korupsi cenderung dilakukan oleh mereka yang memiliki kekuasaan?

\section{PEMBAHASAN}

Istilah korupsi telah banyak didefinisikan dari berbagai disiplin dan sudut pandang ilmu pengetahuan. Korupsi adalah sebuah konsep yang sangat sulit untuk dijelaskan. Secara umum korupsi dapat dikatakan sebagai penggunaan kekuasaan public untuk kepentingan pribadi. Kekuasaan public adalah kekuasaan yang diberikan oleh public, public bisa berarti masyarakat atau organisasi yang ada di dalamnya. Yang perlu juga dipahami adalah bahwa korupsi bukan hanya persoalan hukum namun juga persoalan kultur (Wattimena,2012:12).

Kembali ke pertanyaan awal bahwa mengapa pemegang kekuasaan cenderung melakukan korupsi pada secara budaya mereka dikategorikan orang yang cukup berbudaya. Kalau kita mencoba untuk mencermati pndangan para akhli seperti Nietzsche seorang filosof Jerman, bahwa manusia memiliki kecenderungan untuk berkuasa. Ia berpendapat bahwa manusia dan alam semesta didorong oleh suatu kekuatan purba, yakni kehendak untuk berkuasa (the will to power). Menurut Nietzsche kehendak untuk berkuasa adalah "klain kekuasaan yang paling tiranik, tak penya pertimbangan dan tak dapat dihancurkan". Seluruh realitas dan segala yang ada didalamnya, adalah ledakan sekaligus bentuk lain dari kehendak untuk berkuasa. Ia ada didalam kesadaran sekaligus ketidaksadaran manusia. Kehendak untuk berkuasa adalah dorongan yang mempengaruhi sekaligus membentuk apapun yang ada, sekaligus merupakan hasil dari semua proses realitas itu sendiri. Ia menyarankan bahwa yang perlu dilakukan setiap orang adalah mengenali dan menerima kehendak untuk berkuasa sebagai bagian dari dirinya. Jangan pernah menyangkal bahwa diri kita semua, lepas dari sebaik apa pribadi kita, memiliki kehendak untuk berkuasa atas orang lain dan atas alam semesta (Wattimena,2012:42).

Sampai di sini tentu tidak menjadi persolan. Yang menjadi persoalan adalah manakala kehendak berkuasa tersebut dipergunakan untuk melakukan hal-hal yang bertentangan secara moral dan hukum, dalam hal ini korupsi. Kekuasaan yang disalahgunakan inilah yang bisa dikategorikan melakukan tindakan korupsi. Hal ini bisa terjadi manakala sang aktor memiliki kekuasaan dan lingkungan juga mendukung bagi terjadinya korupsi.

Tindakan sosial terjadi di sepanjang ruang dan waktu, bukan karena paksaan struktur dan juga bukan karena kesadaran agen sematamata. Agen dan struktur terintegrasi dalam keterulangan praktik sosial (Giddens dalam Ritzer dan Goodman, 2005:507). Di dalam dan melalui praktik sosial, para agen memproduksi kondisi-kondisi yang memungkinkan keberadaan aktivitas-aktivitas mereka dan dengan cara itu mereka mengungkapkan diri sebagai aktor (Giddens, 2010:3). Jadi, tindakan sosial tidak dilahirkan oleh paksaan struktur dan kesadaran aktor, tetapi melalui praktik sosial secara terus menerus.

Kontinuitas praktik-praktik sosial mengasumsikan refleksivitas tindakan secara terus menerus, seperti halnya arus kesadaran. Dalam hal ini, Giddens (dalam Ritzer dan Goodman, 2005:509) membedakan dua jenis kesadaran yang mendasari tindakan aktor, yaitu kesadaran diskursif dan kesadaran praktis. Kesadaran diskursif adalah kemampuan melukiskan tindakan dalam kata-kata, sedangkan kesadaran praktis melibatkan tindakan yang dianggap benar oleh aktor tanpa mampu mengungkapkannya dengan kata-kata. Apabila kesadaran diskursif berkaitan dengan stok pengetahuan yang dimiliki para aktor, maka kesadaran praktis justeru inheren dengan rutinisasi kehidupan sosial. Pada kenyataannya, kesadaran diskursif tidak selalu dapat diakses secara langsung oleh kesadaran para aktor dalam berbagai interaksi sosial. Kebanyakan aktor hanya bertindak berdasarkan kesadaran praktis yang inheren dalam rutinitas kehidupan sosial. Oleh karena itu, batas-batas antara kesadaran diskursif dan kesadaran praktis berubah-ubah dan cair sehingga ontologi ruangwaktu sebagai penentu praktik sosial menjadi konsepsi mendasar dalam strukturasi.

Berdasarkan hal tersebut, Giddens (2010:5) 
membangun model stratifikasi yang melibatkan monitoring refleksif, rasionalisasi tindakan, dan motivasi tindakan sebagai serangkaian proses yang melekat. Model ini beroperasi dalam enam unsur teori strukturasi, yaitu (1) agen, agensi; (2) agensi dan kekuasaan; (3) struktur, strukturasi; (4) dualitas struktur; (5) bentukbentuk institusi; dan (6) waktu, tubuh, dan perjumpaan, sebagaimana penjelasan berikut ini.

Pertama, agen, agensi. Monitoring refleksif atas tindakan merupakan unsur tetap dari tindakan sehari-hari yang melibatkan perilaku individu dan perilaku individu-individu yang lain. Para aktor senantiasa memonitor arus aktivitasnya dan berharap aktor-aktor lain juga memonitor aktivitas mereka sendiri. Di samping itu, juga aktor secara rutin memonitor aspekaspek lain yang diciptakan oleh struktur tempat mereka bergerak. Monitoring refleksif inilah yang melahirkan rasionalisasi tindakan, yaitu para aktor berusaha mempertahankan suatu pemahaman teoretis secara terus-menerus tentang landasan-landasan aktivitas mereka secara diskursif. Dengan cara inilah kriteria agen berkompeten dilahirkan dalam perilaku sehari-hari, yaitu aktor mampu menjelaskan tindakannya, jika memang diminta. Monitoring refleksif dibedakan dengan rasionalisasi tindakan berdasarkan motivasinya. Motivasi mengacu pada potensi tindakan, bukan cara bertindak yang dilakukan secara terus-menerus oleh agen bersangkutan. Motif-motif cenderung memiliki hubungan langsung dengan tindakan hanya dalam keadaan-keadaan yang relatif tidak lazim, situasi-situasi yang terputus dari rutinitas. Tindakan yang muncul berdasarkan motif-motif ini cenderung didorong oleh kesadaran praktis, yaitu upaya membangun transisi halus dari agen ke agensi(keagenan) (Giddens, 2010:7-10).

Agensi berkaitan dengan kejadian-kejadian yang melibatkan individu sebagai pelaku. Dalam artian bahwa pelaku dapat bertindak berbeda dalam setiap fase apapun dalam suatu urutan tindakan tertentu (Giddens, 2010:14). Agensi melibatkan diri lebih jauh pada konsekuensi tindakan tidak disengaja, berbeda dengan monitoring refleksif dan rasionalisasi tindakan yang dapat dijelaskan sebagai tindakan kesengajaan. Menurut Giddens (2010:21-22) bahwa konsekuensi-konsekuensi tidak disengaja dari tindakan membentuk kondisi- kondisi terkenali dari tindakan selanjutnya dalam satu siklus (perputaran kausal) umpan balik non-refleksif. Konsekuensi-konsekuensi tidak disengaja itu secara rutin disebarluaskan sebagai sebuah hasil tidak terelakkan dari perilaku rutin yang secara refleksif tetap dipertahankan oleh pelakunya. Hal ini menegaskan bahwa setiap tindakan sosial melahirkan konsekuensi-konsekuensi, baik disengaja maupun tidak disengaja yang seluruhnya dirutinisasi dalam waktu dan ruang sosial.

Kedua, agensi dan kekuasaan. Hubungan logis antara agensi dan kekuasaan mengandaikan bahwa menjadi seorang agen harus mampu menggunakan (secara rutin dalam kehidupan sehari-hari) sederet kekuasaan kausal, termasuk memengaruhi kekuasan-kekuasaan yang dijalankan orang lain (Giddens, 2010:23). Ini berarti bahwa dalam agensi, kekuasaan lebih besar berada pada agen, yakni agen mempunyai kemampuan menciptakan pertentangan dalam kehidupan sosial, bahkan agen tidak akan berarti apa-apa tanpa kekuasaan. Dengan kata lain, aktor berhenti menjadi agen, bila ia kehilangan kemampuan menciptakan pertentangan (Giddens dalam Ritzer dan Goodman, 2005:509-512). Menurut Giddens (2010:25) bahwa kekuasaan dalam sistem sosial memiliki suatu kontinuitas di sepanjang ruang dan waktu yang mengandaikan rutinisasi relasirelasi kemandirian dan ketergantungan di antara para aktor ataupun kelompok dalam konteks interaksi sosial. Ketergantungan menawarkan sejumlah sumber daya yang memberikan kemampuan bagi kelas subordinat untuk memengaruhi aktivitas para aktor dominan. Inilah yang disebut dialektika kendali (dialectic of control) dalam sistem-sistem sosial. Artinya, agensi dan kekuasaan berlangsung secara dialektis dalam keseluruhan interaksi sosial tanpa dominasi, melainkan kondisi ketergantungan.

Ketiga, struktur dan strukturasi. Untuk menjelakan unsur ini, Giddens (2010:40) memberikan penjelasan tentang 'struktur', 'sistem', dan 'strukturasi' secara berbeda dengan kaum strukturalis. Struktur dijelaskan adalah aturan dan sumber daya, atau seperangkat relasi transformasi, terorganisasi sebagai kelengkapan-kelengkapan dari sistem-sistem sosial. Sementara itu, sistem adalah relasi-relasi 
yang direproduksi di antara para aktor atau kolektivitas, terorganisasi sebagai praktikpraktik sosial reguler. Berikutnya, strukturasi adalah kondisi-kondisi yang mengatur keterulangan atau transformasi strukturstruktur, dan karenanya adalah reproduksi sosial itu sendiri. Dengan demikian, menganalisis strukturasi dari sistem-sistem sosial berarti mempelajari cara-cara bagaimana suatu sistem yang tertanam dalam aktivitas-aktivitas aktor tertentu yang berpegang pada aturan-aturan dan sumber daya-sumber daya dalam beragam konteks tindakan, diproduksi dan direproduksi dalam interaksi.

Keempat, dualitas struktur. Menurut Giddens (2010:40-41) bahwa agen dan struktur bukanlah dua fenomena yang terpisah atau dualisme, tetapi mewakili dualitas. Artinya, kelengkapan-kelengkapan struktural dari sistem sosial adalah sarana sekaligus hasil dari praktik-praktik sosial yang terorganisasi secara rutin. Reifikasi relasi-relasi sosial atau naturalisasi diskursif terhadap keadaankeadaan sejarah yang berubah-ubah dan produk-produk tindakan manusia merupakan salah satu dimensi utama ideologi dalam kehidupan sosial. Lebih lanjut dijelaskan bahwa dualitas struktur merupakan landasan utama bagi keterulangan-keterulangan dalam reproduksi sosial di sepanjang ruang-waktu (Giddens, 2010:43).

Kelima, bentuk-bentuk institusi. Pembahasan Giddens (2010:45) tentang institusi-institusi berkaitan dengan kekuasaan dan struktur. Dalam hal ini, Giddens (2010:49-54) mengemukakan tiga dimensi struktural dalam sistem sosial, yaitu signifikansi, dominasi, dan legitimasi yang dipahami dalam skema interpretatif. Struktur signifikansi memproduksi institusi tanda yang menjadi sarana dan hasil dari proses-proses komunikasi agen dalam interaksi. Struktur-struktur signifikansi selalu harus dipahami dalam kaitannya dengan dominasi dan legitimasi. Dominasi merupakan kondisi keberadaan kode-kode signifikansi, di mana kekuasaan dan dominasi tidakterpisahkan dalam asosiasi sosial. Dominasi tergantung pada mobilisasi dua jenis sumber daya, yaitu sumber daya alokatif yang memproduksi institusi ekonomi, dan sumber daya otoritatif yang memproduksi institusi politik. Sementara itu, legitimasi berhubungan dengan regulasi normatif yang memproduksi institusi hukum. Meskipun demikian, tata institusional ini mesti dipahami sebagai penolakan atas substantivitas, yaitu pengandaian bahwa terdapat perbedaan institusional konkret dalam setiap tatanan sosial. Diandaikan misalnya, institusi politik tidak hanya menunjuk pada masyarakat yang memiliki struktur birokrasi, tetapi fenomena 'politik' dapat ditemukan dalam bentuk penataan relasi-relasi otoritas dalam seluruh masyarakat. Artinya, praktik kekuasaan dapat berlangsung kapan pun dan di mana pun melalui mobilisasi sumber daya agen yang di dalamnya dominasi dan legitimasi dibangun dan dilanggengkan.

Perilaku korup jika dilihat dari pandangan ahli sosiologi Giddens ditentukan oleh habitus dan lingkungan. Habitus menghasilkan dan dihasilkan oleh kehidupan sosial. Tindakanlah yang mengantarai habitus dan kehidupan sosial. Di satu pihak, habitus diciptakan melalui praktik (tindakan); di pihak lain, habitus adalah hasil tindakan yang diciptakan kehidupan sosial. Walau habitus adalah sebuah struktur yang diinternaslisasikan, yang mengendalikan pikiran dan pilihan tindakan, namun habitus tidak menentukan. Namun demikian menurut Boudieu, habitus semata-mata mengusulkan apa yang sebaiknya dipikirkan orang dan apa yang sebaiknya mereka pilih untuk dilakukan. Dalam menentukan pilihan, aktor menggunakan pertimbangan mendalam berdasarkan kesadaran, meski proses pembuatan keputusan mencerminkan berperannya habitus. Habistus menyediakan prinsip-prinsip dan dengan prinsip itu aktor membuat pilihan dan memilih strategi yang akan digunakan dalam kehidupan sosial. Bourdieu juga menyatakan bahwa habitus bukanlah struktur yang tetap, tak dapat berubah, tetapi diadaptasi oleh individu yang secara konstan berubah di hadapan situasi yang saling bertentangan dimana mereka berada (Ritzer, 2004: 524)

Lingkungan (field) menurut Bourdieu lebih bersifat relasional ketimbang struktural. Lingkungan adalah jaringan hubungan antarposisi objektif di dalamnya. Keberadaan hubungan ini terlepas dari kesadaran dan kemauan individu. Lingkungan bukanlah interaksi atau ikatan lingkungan bukanlah intersubjektif antara individu. Penghuni posisi mungkin agen individual atau lembaga, dan 
penghuni posisi dikendalikan oleh struktur lingkungan. Dalam kehidupan sosial terdapat sejumlah lingkungan semi otonom (seperti kesenian, keagamaan, ekonomi) dan semuanya dengan logika khususnya sendiri-sendiri dan semuanya membangkitkan keyakinan di kalangan aktor mengenai sesuatu yang dipertaruhkan dalam lingkungan.

Menurut Bourdieu lingkungan adalah sebuah arena pertarungan. Struktur lingkunganlah yang menyiapkan dan membimbing strategi yang digunakan penghuni posisi tertentu (secara individual atau kolektif) yang mencoba melindungi atau meningkatkan posisi mereka untuk memaksakan prinsip penjenjangan sosial yang paling menguntungkan bagi produk mereka sendiri. Lingkungan adalah sejenis pasar kompetisi di mana berbagai jenis modal (ekonomi, kultur, sosial, simbolik) digunakan dan disebarkan. Didalamnya juga termasuk persoalan politik (kekuasaan) ; hierarkhi hubungan kekuasaan di dalam lingkungan politik membantu menata semua lingkungan lain.

Untuk menganalisis masalah lingkungan ini Bourdieu mengajukan tiga langkah proses. Langkah pertama, menggambarkan keutamaan lingkungan kekuasaan (politik) untuk menemukan hubungan setiap lingkungan khusus dengan lingkungan politik. Langkah ke dua menggambarkan struktur objektif hubungan antar berbagai posisi di dalam lingkungan tertentu. Ketiga, analisis harus mencoba menemukan ciri-ciri kebiasaan agen yang menempati berbagai tipe posisi di dalam lingkungan.

Menurut Bourdieu, pada lingkungan atau arena inilah agen saling 'bertarung' memperebutkan posisinya dengan mempertaruhkan paling tidak empat modal yaitu ekonomi, kultural, sosial, dan simbolik. Modal ekonomi (sudah cukup jelas), kultural meliputi berbagai pengetahuan yang sah,modal sosial terdiri dari hubungan sosial yang bernilai antara individu, dan modal simbolik berasal dari kehormatan dan prestise seseorang (Ritzer dan Goodman,2004: 525-526). Teori Bourdieu memusatkan perhatiannya pada hubungan antara habitus. modal dan lingkungan (field, habitus, and capital) (Rey, 2007: 43). Hubungan ini berperan dalam dua cara. Di satu pihak, lingkungan mengondisikan habitus; di pihak lain, habitus menyusun lingkungan sebagai sesuatu yang bermakna, yang mempunyai arti dan nilai ( Ritzer, 2004: 527; Ritzer, 2008: 584).

Pada umumnya kekuasaan dibicarakan sebagai daya atau pengaruh yang dimiliki oleh seseorang atau suatu lembaga untuk memaksakan kehendaknya kepada pihak-pihak lain. Pengertian semacam ini telah digunakan oleh para pengamat sejarah, politik, dan sosial. Kekuasan semacam itu dipandang sebagai hal yang bersifat represif. Akan tetapi Foucault memiliki pandangan yang berbeda dalam melihat kekuasaan. Bagi Foucault "kebenaran" bukanlah sesuatu yang seolah sudah senantiasa ada "di sana" (given) tak tersentuh oleh waktu dan tinggal menemukannya, melainkan terjalin secara intrinsik dalam relasi antara wacana yang digunakan manusia untuk mengungkapkan kebenaran itu, sistem kekuasaan yang berlaku dan kedudukan subjek-subjek yang terlibat. Ketiga hal inipun sekaligus merupakan kenyataan yang menyejarah bersama kebenaran yang direngkuhnya. Dengan kata lain bahwa " kebenaran" suatu wacana tergantung pada apa yang dikatakan, terutama siapa yang mengatakan, kapan dan dimana ia mengatakannya. Ringkasnya kebenaran suatu wacana tergantung pada konteks ( Storey, 2004: 135; Sturrock,2004:175-176 ).

Foucault berusaha menjelaskan bahwa kekuasaan dikendalikan oleh wacana dan bagaimana wacana itu selalu berakar dalam kekuasaan, ' kekuasaan menghasilkan pengetahuan, kekuasaan dan pengetahuan secara langsung saling mempengaruhi, tidak ada hubungan kekuasaan tanpa ada konstitusi korelatif dari bidang pengetahuannya, atau bahwa suatu pengetahuan tidak akan menuntut dan membentuk hubungan kekuasaan pada waktu yang sama. Dengan kata lain Foucault berpandangan bahwa tidak ada pengetahuan abadi yang berlaku di segala jaman. Sementara itu menurut Gidden (2005: 52) dalam ilmu, tidak ada satu pun yang pasti. Tidak ada pengetahuan dalam kondisi modernitas yang merupakan pengetahuan dalam pengertian "lama" dimana " mengetahui" berarti yakin. Ini berlaku pada ilmu alam dan ilmu sosial.

Foucault sebenarnya telah mengadopsi pemikiran Nietzsche (Best,2003:38) tentang hubungan antara kekuasaan dan pengetahuan, tetapi hubungan itu lebih banyak dianalisisnya 
secara sosiologis. Dalam genealogis kekuasaan, Faucoult membahas bagaimana orang mengatur diri sendiri dan orang lain melalui produksi pengetahuan. Di antaranya, ia melihat pengetahuan menghasilkan kekuasaan dengan mengangkat orang menjadi subjek dan kemudian memerintah subjek dengan pengetahuan. Foucault juga memberi perhatian cukup besar pada teknik, teknologi yang berasal dari pengetahuan (terutama yang berasal dari ilmu pengetahuan ilmiah), dan memperhatikan cara teknologi digunakan oleh berbagai instansi untuk memaksakan kekuasaan terhadap manusia. Meski ia melihat kaitan antara pengetahuan dan kekuasaan, namun ia yakin bahwa pengetahuan dan kekuasaan selalu bersaing; antara keduanya selalu terjadi resistensi ( Ritzer, 2003: 115; Ritzer, 2005: 610).

Foucoult juga melihat bahwa pengetahuan sebagai sesuatu yang dapat digunakan secara negatif untuk memanipulasi penerimaan normatif masyarakat. Demikian juga Bourdieu juga memandang pengetahuan sebagai sesuatu yang dikontestasikan dan memberi kekuasaan yaitu kekuasaan simbolik (Rochman, 2015:164).

Rochman (2015:158) juga berpandangan bahwa korupsi adalah tindakan pelanggaran terhadap norma yang berkembang dalam masyarakat. Jika memang demikian halnya maka yang perlu dilakukan dalam upaya untuk memperkuat norma sosial dalam masyarakat, salah satu jalan yang dapat dilakukan adalah memperkuat norma sosial m,asyarakat melalui penguatan agama. Dipilihnya agama degan pertimbangan bahwa sebagai masyarakat timur yang mendapat label sebagai masyarakat spiritual mestinya agama memiliki tawaran untuk itu.

Harus pula disadari bahwa agama memiliki wajah ganda, sekarang tergandung pada pemahaman mereka terhadap agamanya. Wajah ganda agama ini menurut Nottingham (1992) karena di satu sisi agama bisa merupakan fokus potensial bagi munculnya pembaharuan yang kreatif sekaligus juga kekacauan dalam masyarakat. Soemardjo (2003) fenomena agama dalam hidup umat manusia adalah bahwa agama mampu menyatukan manusia, tetapi agama juga dapat memecah belah manusia. Secara rasional tentu yang diharapkan bahwa agama fungsional memberikan rasa aman dan nyaman bagi umat manusia.
Agama dalam bentuk apapun selalu muncul sebagai kebutuhan ideal umat manusia. Oleh karena itu peranan agama sangat menentukan dalam setiap kehidupan, dan tanpa agama manusia tidak akan hidup sempurna. Peranan agama menjadi sangat penting dalam kehidupan manusia karena agama terkait dengan kebudayaan dalam masyarakat sehingga agama dan masyarakat saling mempengaruhi. Ini berarti ide tentang kesempurnaan hidup sangat tergantung kepada agama karena ajarannya yang diwahyukan oleh Tuhan haruslah dipercaya sedemikian rupa. Mengingat kebenaran agama yang adalah kebenaran wahyu sehingga di dalamnya tidak dibenarkan adanya dialog tentang keyakinan benar, tetapi kepercayaan (religious).

Agama berisi ajaran-ajaran tentang kebenaran yang tertinggi dan mutlak tentang eksistensi manusia dan petunjuk-petunjuk untuk hidup selamat di dunia dan di akhirat (setelah mati). Agama sebagai sistem keyakinan dapat menjadi bagian dari sistem nilai yang ada dalam kebudayaan masyarakat bersangkutan, dan menjadi pendorong atau penggerak serta pengontrol dari tindakan-tindakan para anggota masyarakat tersebut untuk tetap berjalan sesuai dengan nilai-nilai kebudayaan dan ajaran-ajaran agamanya. Dalam hal ini agama sebagai sumber moral tidaklah mungkin mengandung kesalahan-kesalahan ataupun keburukankeburukan yang dapat menyebabkan manusia (penganutnya) bertindak ke arah yang kontra produktif terhadap kesempurnaan hidupnya. Dengannya agama menjadi pedoman bagi seluruh nilai kesempuranaan hidup yang layak diperebutkan dan perjuangkan dalam segala lini kehidupan karena hanya dengan demikian agama benar-benar menjadi milik sebuah masyarakat. Ini sebabnya agama benar-benar dapat hidup dalam setiap hati masyarakat sebagai pembakar semangat sosial dan pewarna bagi keindahan kebudayaan suatu masyarakat yang layak disebut sebagai masyarakat beradab (Utama, 2013).

\section{PENUTUP}

Berdasarkan paparan singkat tersebut di atas dapat disimpulkan beberapa hal sebagai berikut. Pertama, bahwa sejalan dengan pandangan Nietzsche setiap orang secara potensial memiliki 
kehendak bebas yang bias mengarah pada perilaku korupsi karena terdorong keinginan berkuasa (will to power). Kedua, di samping agen, struktur juga memiliki potensi untuk melakukan korupsi. Hal ini bisa terjadi manakala agen dan struktur terlibat dalam kontestasi di ranah publik karena di situ akan dipertaruhkan berbagai bentuk modal seperti modal ekonomi, kultural, sosial, dan simbolik. Ketiga, jika diasumsikan bahwa korupsi adalah pelanggaran terhadap norma, logikanya penguatan norma masyarakat harus dilakukan. Salah satunya adalah dengan memperkuat nilai-nilai agama.

\section{DAFTAR PUSTAKA}

Best, Steven \& Douglas Kellner. 2003. Teori Postmodern, Interogasi Kritis. Gresik: Boyan Publishing. Nottingham, Elizabeth K. 1992. Agama dan Masyarakat. Jakarta : Rajawali Press.

Ritzer, George. 2003. Teori Sosial Postmodern. Yogyakarta : Kreasi Wacana.

Ritzer, George - Douglas J. Goodman. 2005. Teori Sosiologi Modern. Jakarta : Prenada Media.

Rochman, Meuthia Ganie- Rochman Achwan. 2015. Sosiologi Korupsi. Isu, Konsep, dan Perdebatan. Jakarta : UI Press.

Sumardjo, Jakob. 2003. Mencari Sukma Indonesia. Pendataan Kesadaran Keindonesiaan di Tengah Letupan Disintegrasi Sosial Kebangsaan. Yogyakarta: AK Group.

Storey, John. 2004. Teori Budaya dan Budaya Pop. Memetakan Lanskap Konseptual Cultural Studies. Yogyakarta : Pustaka Pelajar.

Sturrock, John. 2004. Strukturalisme Post-strukturalisme dari Levi-Strauss sampai Derrida, terjemahan dari Structuralism and Since. Surabaya : Jawa Post Press.

Utama, I Wayan Budi. 2013. Agama dalam Praksis Budaya. Denpasar : Pascasarjana Universitas Hindu Indonesia.

Wattimena, Reza A.A.2012. Filsafat Anti Korupsi. Membedah Hasrat Kuasa, Perburuan Kenikmatan, dan Sisi Hewani Manusia di balik Korupsi. Jogjakarta : Kanisius. 